\title{
PERUBAHAN KUALITAS TANAH PADA SISTEM PERTANIAN KONVENSIONAL DAN ORGANIK (DESA PISAK KECAMATAN TUJUHBELAS KABUPATEN BENGKAYANG)
}

\author{
Feni Febrianti ${ }^{1}$, Rossie W. Nusantara ${ }^{\mathbf{1}}$, Feira B. Arief ${ }^{\mathbf{1}}$ \\ ${ }_{1}^{1}$ Program Studi Ilmu Tanah Universitas Tanjungpura, Pontianak
}

Email korespondensi: fenif@student.untan.ac.id

\begin{abstract}
Abstrak
$10.26418 /$ pipt.2021.45

Sistem pertanian organik merupakan cara bertani dengan mengelola tanah sepenuhnya menggunakan bahan-bahan organik. Pupuk organik yang diberikan mampu memperbaiki sifat fisika tanah, kimia tanah, dan biologi tanah. Penelitian ini bertujuan mengetahui perubahan kualitas tanah pertanian organik pada pengelolaan lahan sebelumnya, yakni sistem pertanian konvensional di Desa Pisak Kecamatan Tujuhbelas Kabupaten Bengkayang. Berdasarkan waktu periode perubahan lahan sistem pertanian organik sejak Mei 2019 dan Agustus 2018 serta lahan sistem pertanian konvensional sebagai kontrol menggunakan metode minimum data set. Hasil penelitian menunjukkan bahwa sistem pertanian organik dapat memperbaiki parameter tanah. Hal ini ditunjukkan lahan sistem pertanian organik sejak Mei 2019 dan Agustus 2018 mengalami kenaikan berturut-turut dari 0,43, 0,48 dan 0,53 dengan kriteria sedang. Kenaikan nilai indeks kualitas terjadi karena indikator kunci yang didapat dari Principal Component Analysis (PCA) pada lahan sistem pertanian organik untuk skoring ( $\mathrm{Si}$ ) pengali nilai PCA (Wi) lebih tinggi dari lahan sistem pertanian konvensional. Nilai indeks kualitas tanah tertinggi adalah indikator C-Organik, N-Total, dan kejenuhan basa. Hal ini disebabkan kandungan C-Organik menyatakan kandungan bahan organik yang mempunyai peranan penting untuk penentuan kualitas tanah dalam produksi pertanian dan kelestarian lingkungan melalui pengaruhnya terhadap sifat fisika, kimia dan biologi tanah.
\end{abstract}

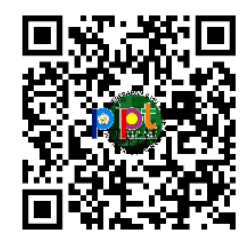

Kata kunci: pertanian organik, pertanian konvensional, indeks kualitas tanah

\section{PENDAHULUAN}

Pertanian konvensional merupakan sistem berlandas high input energy dengan menambahkan bahan kimia seperti pupuk dan pestisida kimia. Altieri (2002) mengatakan bahwa sistem pertanian konvensional digunakan untuk mengembangkan mekanisasi dalam mencapai hasil panen yang lebih tinggi, mengurangi tenaga kerja manusia, peningkatan penggunaan pengendalian gulma dan hama kimia, dan penurunan permintaan hasil kotoran hewan ternak. Pada masa orde baru, pertanian konvensional di masa revolusi hijau telah berhasil meningkatkan hasil produksi tanaman. Namun secara global, seiring dengan berkembangnya pertanian konvensional yang di lakukan secara terus menerus memberi dampak pada produktivitas tanah yang menurun. Hal ini karena penambahan pupuk dan pestisida kimia yang merusak lingkungan. Pemberian pupuk kimia yang berkonsentrasi dalam penambahan unsur hara anorganik yang mudah larut dilakukan terus menerus dapat membahayakan fauna tanah sehingga sistem pertanian konvensional ini dianggap tidak arif (Sutanto, 2002). Sistem pertanian konvensional juga dapat menyebabkan hilangnya bahan organik tanah, kemasaman tanah yang meningkat dan hilangnya unsur hara di dalam tanah (Hillel, 1992).

Seiring meningkatnya permintaan akan produksi pangan untuk memenuhi kebutuhan populasi global yang terus bertambah, penggunaan pupuk kimia, pestisida dan ketergantungan yang tinggi pada pengolahan tanah terus menjadi metode pengelolaan yang lazim. Akibatnya akan tercermin dalam kualitas tanah yang berkurang dan mempengaruhi kemampuan tanah untuk terus menghasilkan makanan. Berbeda dengan pertanian organik, sistem ini mencoba meniru atau mengikuti proses alam yang cenderung meningkatkan kesehatan tanah dan tanaman 
sekaligus melestarikan tanah dan sumber daya air (Gomiero et al., 2011). Menurut Badgley (2007), pertanian organik memanfaatkan proses siklus nutrisi alami dan tidak menggunakan pestisida kimia untuk mempertahankan atau regenerasi kualitas tanah sehingga istilah organik ini mengacu pada praktik pertanian berkelanjutan. Suwantoro (2008) menyebutkan bahwa pertanian organik merupakan suatu sistem pertanian berwawasan lingkungan, untuk pertanian yang berkelanjutan, dan diyakini dapat menyuburkan tanah dengan asupan pupuk organik. Dalam pertanian organik, bahan organik merupakan hal terpenting dalam menaikkan kualitas tanah. Hal ini disebutkan oleh Birkhofer et al. (2008) bahwa dalam sistem pertanian organik, organisme di dalam tanah menjadi hal yang sangat penting untuk terbentuknya struktur tanah, dinamika karbon tanah, dan unsur hara yang dimineralisasi.

Beberapa tahun ini, masyarakat Desa Pisak yang bertani di lahan mereka masingmasing satu persatu mencoba beralih dari sistem konvensional menjadi sistem organik. Hal ini mereka lakukan karena beberapa lahan yang biasa mereka olah untuk tanaman hortikultura dan sayur-sayuran tidak dapat ditanam lagi untuk tanaman tersebut dikarenakan tanah yang mulai mengeras dan hanya cocok untuk pohon tahunan. Oleh sebab itu, perlunya dilakukan penelitian untuk mengetahui kualitas tanah pada perubahan sistem pertanian tersebut.

Penelitian bertujuan untuk mengkaji perubahan kualitas tanah pada lahan sistem pertanian konvensional menjadi organik dilihat dari Indeks Kualitas Tanah di Desa Pisak Kecamatan Tujuh Belas Kabupaten Bengkayang.

\section{METODOLOGI}

Penelitian ini dilakukan di Desa Pisak Kecamatan Tujuh Belas Kabupaten Bengkayang pada dua tipe lahan sistem pertanian konvensional yang berubah menjadi sistem pertanian organik, yaitu sejak Mei 2019 dan Agustus 2018 serta lahan sistem pertanian konvensional sebagai kontrol.

Pengambilan sampel dilakukan di lapangan dengan metode grid diagonal sampling. Selanjutnya sampel dianalisis di Laboratorium Kimia dan Kesuburan Tanah dan Laboratorium Fisika dan Konservasi Tanah Fakultas Pertanian Universitas Tanjungpura. Waktu yang diperlukan dalam penelitian di lapangan dan di laboratorium selama 5 bulan (09 Agustus 2020 - 03 Desember 2020) mulai dari persiapan, pelaksanaan di lapangan, dan penyajian hasil. Pengambilan sampel ditentukan dengan luasan lahan pada masing-masing lokasi penelitian.

Parameter penelitian terdiri dari parameter sifat fisika, kimia, dan biologi tanah. Parameter fisika tanah antara lain bobot isi tanah, porositas total tanah, dan kadar air kapasitas lapangan. Parameter kimia tanah antara lain $\mathrm{pH}, \mathrm{N}$-Total, Ptersedia, K-dd, Na-dd, Ca-dd, Mg-dd, Kejenuhan Aluminium, Fe, Kejenuhan Basa, KTK, C-Organik, dan C/N Rasio. Parameter Biologi tanah, yaitu menghitung kepadatan cacing tanah. Metode analisis data dalam menentukan indeks kualitas tanah menggunakan minimum data set dengan aplikasi principal component analysis (PCA) dalam program SPSS dan untuk melihat perbedaan antara setiap lahan digunakan uji Analisis of Varian (ANOVA) dan uji berganda Duncan Multiple Range Test (DMRT).

Tabel 1. Riwayat Penggunaan Lahan

\begin{tabular}{|c|c|l|l|l|}
\hline No & $\begin{array}{c}\text { Sistem } \\
\text { Lahan }\end{array}$ & Pengolahan & \multicolumn{1}{|c|}{ Vegetasi } & \multicolumn{1}{c|}{ Pupuk dan Pestisida } \\
\hline 1. & Konvensional & $\begin{array}{l}\text { Maximum } \\
\text { tillage }\end{array}$ & $\begin{array}{l}\text { Cabai rawit, daun bawang, } \\
\text { dan kacang buncis }\end{array}$ & $\begin{array}{l}\text { Pupuk kimia: SP-36, mutiara 16-16-16, } \\
\text { mutiara grower dan karate plus boroni } \\
\text { Pestisida: insektisida, fungisida }\end{array}$ \\
\hline
\end{tabular}




\begin{tabular}{|c|c|c|c|c|c|}
\hline No & $\begin{array}{l}\text { Sisten } \\
\text { Lahar }\end{array}$ & & Pengolahan & Vegetasi & Pupuk dan Pestisida \\
\hline 2. & $\begin{array}{l}\text { Organik } \\
\text { (Sejak } \\
2019) \\
\end{array}$ & \pm & $\begin{array}{l}\text { Minimum } \\
\text { tillage }\end{array}$ & $\begin{array}{l}\text { Cabai rawit, terong, dan } \\
\text { kacang buncis }\end{array}$ & $\begin{array}{l}\text { Pupuk organik: kotoran ayam, kotoran } \\
\text { kambing, pupuk organik cair dan kapur } \\
\text { Pestisda: Nabati }\end{array}$ \\
\hline 3. & $\begin{array}{l}\text { Organik } \\
\text { (Sejak } \\
2018)\end{array}$ & \pm & $\begin{array}{l}\text { Maximum } \\
\text { tillage }\end{array}$ & $\begin{array}{l}\text { Kacang buncis, terong ungu, } \\
\text { timun, kacang panjang, } \\
\text { gambas, dan cabai rawit. }\end{array}$ & $\begin{array}{l}\text { Pupuk organik: kompos dan pupuk } \\
\text { organik cair } \\
\text { Pestisida: Nabati }\end{array}$ \\
\hline
\end{tabular}

Sumber: (Penulis, 2021)

Data sifat fisika, kimia, dan biologi tanah dianalisis statistik menggunakan Principal Component Analisis (PCA) dengan menggunakan aplikasi SPSS versi 23. Penggunaan PCA untuk menentukan satuan data set minimum dari indikator sifat-sifat tanah, yakni fisika, kimia, dan biologi tanah yang mewakili fungsi-fungsi tanah. Penggabungan skor-skor indikator ke dalam suatu indeks kualitas tanah dilakukan menggunakan rumus oleh Andrews et al. (2002).

$$
S Q I / \mathrm{IKT}=\sum_{i=1}^{n} W i S i
$$

Keterangan:

IKT = Indeks Kualitas Tanah

$\mathrm{Wi}=$ Faktor Pombobot (Indeks Bobot)

$\mathrm{Si}=$ Skor Indikator

$\mathrm{N}=$ Jumlah Indikator Kualitas Tanah

Tabel 2: Kriteria Kualitas Tanah

\begin{tabular}{|c|c|c|}
\hline $\begin{array}{c}\text { No } \\
.\end{array}$ & $\begin{array}{c}\text { Kelas } \\
\text { Nilai }\end{array}$ & $\begin{array}{c}\text { Kriteria Kualitas } \\
\text { Tanah }\end{array}$ \\
\hline 1. & $\begin{array}{c}0,80- \\
1,00\end{array}$ & Sangat Baik \\
\hline 2. & $\begin{array}{c}0,60- \\
0,79\end{array}$ & Baik \\
\hline 3. & $\begin{array}{c}0,40- \\
0,59\end{array}$ & Sedang \\
\hline 4. & $\begin{array}{c}0,20- \\
0,39\end{array}$ & Rendah \\
\hline 5. & $\begin{array}{c}0,00- \\
0,19\end{array}$ & Sangat Rendah \\
\hline
\end{tabular}

Sumber: (Partoyo, 2005)

\section{HASIL DAN PEMBAHASAN}

\section{Sifat Fisika Tanah}

Hasil pengukuran sifat fisika tanah pada pertanian konvensional dan organik dapat dilihat bahwa tanah pada sistem pertanian organik dapat menaikkan porositas total tanah hal ini disertai dengan bobot isi tanah yang menurun.

Tabel 3: Pengukuran Parameter Sifat Fisika Tanah Lahan Penelitian

\begin{tabular}{|l|c|c|c|}
\hline $\begin{array}{l}\text { Parameter/ } \\
\text { Sistem }\end{array}$ & $\begin{array}{c}\text { Konven- } \\
\text { sional }\end{array}$ & $\begin{array}{c}\text { Organik - } \\
\text { Mei 2019 }\end{array}$ & $\begin{array}{c}\text { Orga } \\
\text { nik - } \\
\text { Agus } \\
\text { tus } \\
\mathbf{2 0 1 8}\end{array}$ \\
\hline $\begin{array}{c}\text { Bobot Isi } \\
\left(\mathrm{g} / \mathrm{cm}^{3}\right)\end{array}$ & 0,84 & 0,83 & 0,79 \\
\hline $\begin{array}{c}\text { Porositas } \\
\text { Total (\%) }\end{array}$ & 60,65 & 61,83 & 62,78 \\
\hline $\begin{array}{c}\text { Kadar Air } \\
\text { KL (\%) }\end{array}$ & 51,91 & 53,33 & 47,32 \\
\hline
\end{tabular}

Vadari et al. (2014) menyebutkan bahwa pengolahan tanah pada pertanian intensif dapat menekan ruang pori menjadi lebih sedikit dibandingkan dengan tanah yang tidak pernah diolah. Pada kadar air kapasitas lapangan, pertanian organik sejak Mei 2019 memiliki angka yang paling tinggi, diikuti oleh lahan pertanian konvensional, dan organik sejak Agustus 2018 walau tidak berbeda nyata secara signifikan. Kadar air kapasitas lapangan menunjukkan air yang tersedia bagi tanaman.

\section{Sifat Kimia Tanah}

Sifat kimia tanah pada pertanian konvensional dan organik berbeda nyata pada parameter P-tersedia, K-dd, Na-dd dan Fe. Sedangkan pada parameter lain seperti $\mathrm{pH}, \mathrm{C}$ - 
Organik, N-total, Ca-dd, Mg-dd, KTK, KB, Kejenuhan $\mathrm{Al}$ dan $\mathrm{C} / \mathrm{N}$ Rasio tidak berbeda nyata (Tabel 4).

Nilai $\mathrm{pH}$ tanah tidak berpengaruh pada lahan sistem pertanian organik dan konvensional. Beberapa sifat kimia yang berpengaruh pada $\mathrm{pH}$ tanah antara lain K-dd dan Na-dd. Primadani (2008) menyebutkan bahwa $\mathrm{pH}$ berpengaruh untuk unsur hara tanaman dalam penggunaan lahan untuk media tumbuh tanaman. Penggunaan lahan mempengaruhi indeks kualitas tanah. Kadar keasaman $(\mathrm{pH})$ tanah juga berhubungan erat dengan kejenuhan basa, $\mathrm{pH}$ rendah dipengaruhi oleh kejenuhan basa yang rendah, tanah dengan $\mathrm{pH}$ tinggi maka kejenuhan basa juga akan tinggi (Hardjowigeno, 2010).

Tabel 4: Pengukuran Parameter Sifat Kimia Tanah Lahan Penelitian

\begin{tabular}{|c|c|c|c|}
\hline $\begin{array}{l}\text { Parameter/ } \\
\text { Sistem }\end{array}$ & $\begin{array}{l}\text { Konven- } \\
\text { sional }\end{array}$ & $\begin{array}{l}\text { Organik - } \\
\text { Mei } 2019\end{array}$ & $\begin{array}{c}\text { Orga } \\
\text { nik - } \\
\text { Agus } \\
\text { tus } \\
2018\end{array}$ \\
\hline $\mathrm{pH}$ & $4,41^{\mathrm{a}}$ & $4,57^{\mathrm{a}}$ & $4,37^{\mathrm{a}}$ \\
\hline $\begin{array}{c}\text { C-Organik } \\
(\%)\end{array}$ & $4,47^{\mathrm{a}}$ & $4,31^{\mathrm{a}}$ & $4,71^{\mathrm{a}}$ \\
\hline N-Total $(\%)$ & $0,67^{a}$ & $0,65^{a}$ & $0,69^{\mathrm{a}}$ \\
\hline $\begin{array}{l}\text { P-Tersedia } \\
\quad(\mathrm{ppm})\end{array}$ & $12,04^{b}$ & $15,71^{\mathrm{b}}$ & $\begin{array}{c}67,14 \\
\mathrm{a}\end{array}$ \\
\hline $\begin{array}{c}\text { Ca-dd } \\
\left(\mathrm{cmol}^{(+)} \mathrm{kg}^{-1}\right)\end{array}$ & $0,86^{\mathrm{a}}$ & $1,15^{\mathrm{a}}$ & $1,29^{\mathrm{a}}$ \\
\hline $\begin{array}{c}\mathrm{Mg}-\mathrm{dd} \\
\left(\mathrm{cmol}^{(+)} \mathrm{kg}^{-1}\right)\end{array}$ & $0,59^{\mathrm{a}}$ & $0,67^{\mathrm{a}}$ & $0,47^{\mathrm{a}}$ \\
\hline $\begin{array}{c}\mathrm{K}-\mathrm{dd} \\
\left(\mathrm{cmol}^{(+)} \mathrm{kg}^{-1}\right)\end{array}$ & $0,16^{\mathrm{b}}$ & $0,35^{\mathrm{a}}$ & $0,31^{\mathrm{a}}$ \\
\hline $\begin{array}{c}\mathrm{Na}-\mathrm{dd} \\
\left(\mathrm{cmol}^{(+)} \mathrm{kg}^{-1}\right)\end{array}$ & $0,26^{\mathrm{b}}$ & $0,57^{\mathrm{a}}$ & $0,51^{\mathrm{a}}$ \\
\hline $\begin{array}{c}\mathrm{KTK} \\
\left(\mathrm{cmol}^{(+)} \mathrm{kg}^{-1}\right)\end{array}$ & $14,49^{\mathrm{a}}$ & $14,45^{\mathrm{a}}$ & $\begin{array}{c}15,21 \\
\mathrm{a}\end{array}$ \\
\hline $\mathrm{KB}(\%)$ & $13,00^{\mathrm{a}}$ & $19,02^{\mathrm{a}}$ & $7,02^{\mathrm{a}}$ \\
\hline Kej-Al (\%) & $67,74^{\mathrm{a}}$ & $66,83^{\mathrm{a}}$ & $\underset{\mathrm{a}}{34,10}$ \\
\hline $\begin{array}{c}\text { C/N Rasio } \\
(\%)\end{array}$ & $11,84^{\mathrm{a}}$ & $11,74^{\mathrm{a}}$ & $\begin{array}{c}10,84 \\
\text { a }\end{array}$ \\
\hline $\mathrm{Fe}(\mathrm{ppm})$ & $38,64^{\mathrm{b}}$ & $60,23^{\mathrm{ab}}$ & $\underset{\mathrm{a}}{51,80}$ \\
\hline
\end{tabular}

Keterangan: angka-angka yang diikuti dengan huruf yang sama berbeda tidak nyata pada uji Anova dan DMRT pada taraf kepercayaan $5 \%$
Persentase $\mathrm{C} / \mathrm{N}$ Rasio pada tiga lokasi pengamatan diperoleh dari perhitungan persentase C-organik dibagi dengan N-total. Besar kecilnya nilai $\mathrm{C} / \mathrm{N}$ rasio dipengaruhi oleh kandungan $\mathrm{C}$-organik dan $\mathrm{N}$-total pada hasil penelitian ini yang paling berpengaruh adalah kandungan C-organik tanah. Persentase kandungan C-organik adalah indikator total bahan organik tanah yang tersedia di dalam tanah. Sistem pertanian organik terlama, yaitu sejak Agustus 2018 mampu menaikkan C-Organik pada tanah walau tidak berbeda nyata. C-Organik yang tinggi menunjukkan kandungan bahan organik pada lahan tersebut tinggi. N-Total pada kedua sistem pertanian juga tidak berbeda nyata. Berbeda dengan Fosfor tersedia di tanah, pada pertanian organik sejak Mei 2018 mengalami kenaikan yang sangat tinggi. Hal ini disebabkan karena penambahan pupuk $\mathrm{P}$ dan pelepasan jerapan $\mathrm{P}$ dari $\mathrm{Al}$ dan $\mathrm{Fe}$ akibat ditambahnya bahan organik.

P-tersedia yang tinggi pada lahan pertanian organik sejak bulan Agustus 2018 karena adanya bahan organik yang tinggi dari pupuk kandang dan pupuk hijau. Karena pada lahan tersebut juga memiliki nilai C-organik yang tinggi $(4,71 \%)$ diantara lahan yang lainnya. Syafruddin (2019) mengatakan bahwa tingkat C-Organik tanah dipengaruhi sebagian besar pada situasi-kondisi dan jenis pertanian, selain dipengaruhi oleh waktu, bahan organik tanah dapat ditingkatkan oleh pupuk kandang, kompos dan sampah organik serta rotasi tanaman.

Persentase kejenuhan aluminum pada tiga lokasi penelitian diperoleh dari hasil perhitungan beberapa parameter analisis seperti Al-dd, H-dd, K-dd, Ca-dd, Mg-dd, Na-dd, H-dd, Al-dd dan dikalikan dengan $100 \%$. Rendah kandungan K-dd pada sistem pertanian konvensional dibandingkan dengan sistem pertanian organik dikarenakan tidak ada pemupukan jangka panjang dan berkesinambungan. Na-dd diikuti dengan penurunan nilai $\mathrm{pH}$ dan kandungan K-dd di dalam tanah. Natrium sangat sensitif terhadap pencucian sehingga natrium tanah yang tersedia dapat terbuang. Penurunan nilai $\mathrm{Na}-$ 
dd diikuti dengan penurunan nilai $\mathrm{pH}$ tanah. Ketersediaan Ca-dd umumnya berasal dari batu kapur dan serasah tanaman. Tingkat kemasaman juga menjadi faktor penyebab kesediaan unsur Ca-dd dalam tanah. Pada tanah lembap, kalsium bersama ion hidrogen adalah kation-kation yang dominan pada komplek absorsi (Isnaini 2006).

Rendahnya ketersediaan Mg dalam tanah dapat disebabkan karena hilang dari tanah. Kehilangan magnesium seperti juga kalsium yang disebabkan oleh erosi, akibat pencucian dan diangkut tanaman atau organisme hidup lainnya.

\section{Sifat Biologi Tanah}

Perhitungan kepadatan cacing tanah pada lahan sistem pertanian konvensional tidak berbeda nyata dengan kedua lahan sistem pertanian organik (Tabel 5). Hal ini karena kondisi lahan sistem pertanian organik pengolahannya menggunakan pupuk organik dan tidak menggunakan pestisida kimia sedangkan pada lahan sistem pertanian konvensional pengolahannya di kelola secara intensif oleh manusia dengan menggunakan penggunaan pupuk kimia maupun pestisida. Agustina (2016) mengatakan bahan organik berpengaruh pada cacing tanah. Hal ini ditunjukkan pada korelasi positif antara bahan organik dan cacing tanah bahwa semakin tinggi bahan organik maka semakin tinggi kepadatan cacing tanah.
Tabel 5: Perhitungan Kepadatan Cacing Tanah Lahan Penelitian

\begin{tabular}{|l|c|c|c|}
\hline $\begin{array}{l}\text { Parameter/Siste } \\
\text { m }\end{array}$ & $\begin{array}{c}\text { Konve } \\
\text { n- } \\
\text { sional }\end{array}$ & $\begin{array}{c}\text { Organ } \\
\text { ik - } \\
\text { Mei } \\
\mathbf{2 0 1 9}\end{array}$ & $\begin{array}{c}\text { Organi } \\
\text { k - } \\
\text { Agustus } \\
\mathbf{2 0 1 8}\end{array}$ \\
\hline $\begin{array}{c}\text { Kepadatan Cacing } \\
\left.\text { Tanah (Ekor/m }{ }^{2}\right)\end{array}$ & 284,80 & 377,60 & 473,60 \\
\hline
\end{tabular}

\section{Indeks Kualitas Tanah}

Indikator yang telah ditentukan untuk penelitian ini di antaranya parameter sifat fisika, kimia, dan biologi tanah setelah mengikuti syarat analisis faktor menggunakan aplikasi PCA dalam program pengolah data SPSS 23 menghasilkan 9 parameter yang tereduksi dari 17 parameter yang ada, sehingga didapatkan 9 indikator kunci untuk menentukan indeks kualitas tanah. Nilai tertinggi dari kolom tersebut dipergunakan sebagai indeks bobot (w) masing-masing indikator tanah. Setelah diperoleh nilai (w) tersebut digunakan sebagai pengali nilai (s) skoring masingmasing indikator tanah sehingga skoring $(\mathrm{Si})$ mengikuti indikator kunci yang ada. Nilai rata-rata skoring ( $\mathrm{Si}$ ) dari skor setiap data parameter dikalikan dengan indeks bobot (Wi). Penskoran tersebut menggunakan sistem pengamatan didasarkan LPT 1983 dan kriteria penskoran. Setelah melakukan penskoran setiap indikator kunci pada berbagai sistem penggunaan lahan indeks kualitas tanah diukur dengan cara mengalikan hasil skoring dan indeks bobot dapat dilihat pada Gambar 1.

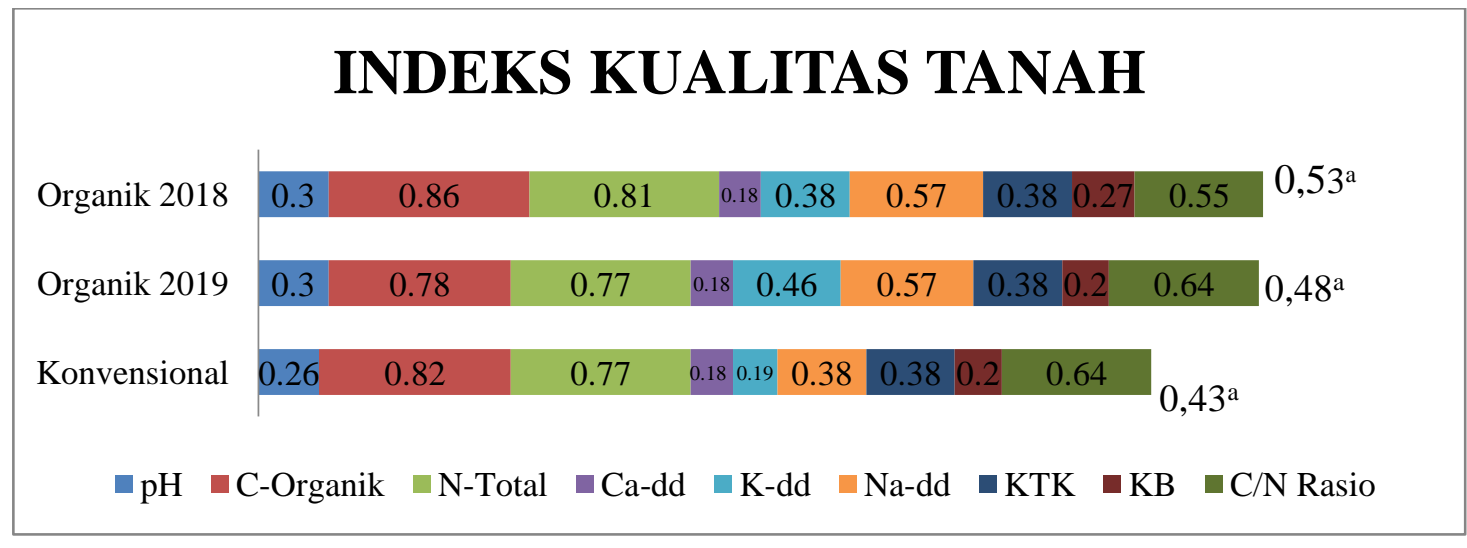

Gambar 1: Grafik sebaran Indeks Kualitas Tanah di Lahan Penelitian

Keterangan : angka-angka yang diikuti dengan huruf yang sama berbeda tidak nyata pada uji Anova dan DMRT pada taraf kepercayaan $5 \%$ 
Berdasarkan Gambar 1 dapat dilihat bahwa sebaran indeks kualitas tanah pada lahan sistem pertanian konvensional dan lahan sistem pertanian organik sejak Mei 2019 dan Agustus 2018 berada pada kategori sedang dengan kelas nilai $0,40-0,59$. Tiga lahan pertanian ini memiliki nilai indeks kualitas tanah tidak berbeda nyata berdasarkan uji Duncan. Hal ini dikarenakan oleh beberapa sifat penyusun indikatornya. Indeks kualitas tanah terendah terdapat pada lahan sistem pertanian konvensional, yaitu sebesar 0,43 kemudian disusul oleh lahan sistem pertanian organik sejak Mei 2019, yaitu sebesar 0,48 , dan lahan sistem pertanian organik sejak Agustus 2018 yaitu sebesar 0,53 .

Lahan sistem pertanian organik sejak Agustus 2018 memiliki nilai indeks kualitas tanah tertinggi dengan indikator C-Organik, $\mathrm{N}$-Total dan KB yang lebih tinggi dari pada lahan sistem pertanian organik sejak Mei 2019 dan lahan sistem pertanian Konvensional. Kandungan C-Organik menyatakan kandungan bahan organik di dalam tanah. Menurut Supriyadi (2008), kandungan organik memiliki peran tambahan untuk menentukan produksi pertanian serta kualitas tanah dalam kelestarian lingkungan melalui pengaruh terhadap sifat fisika, kimia, dan biologi tanah. Oleh karena itu, bahan organik tanah adalah suatu hal yang utama dalam menaikkan kualitas tanah. Kandungan N-Total pada tanah dipengaruhi oleh keberadaan nitrogen di dalam tanah. Sumber nitrogen itu berasal dari kandungan organik tanah, dengan diikat oleh mikroorganisme tanah, pupuk serta air hujan (Hardjowigeno, 2010). Kejenuhan Basa (KB) secara relatif ditentukan oleh jumlah reaksi tanah $(\mathrm{pH})$ dan kation basa.

Nilai pH, K-dd, dan Na-dd lahan sistem pertanian organik memiliki nilai yang lebih tinggi dari pada lahan sistem pertanian konvensional sehingga terdapat perubahan indeks kualitas tanah dari lahan sistem pertanian konvensional menjadi organik dengan komoditas tanaman hortikultura. Nilai $\mathrm{pH}$ ditentukan oleh pemakaian pupuk organik dan adanya pengelolaan tanah sebagai tambahan hara untuk tanah di lahan pertanian. Kadar keasaman $(\mathrm{pH})$ tanah yang disebabkan oleh pemakaian pupuk pada penggunaan lahan sistem pertanian konvensional mempunyai $\mathrm{pH}$ yang lebih rendah dibanding lahan sistem pertanian organik. Nilai K-dd dapat dilihat bahwa K-dd tanah pada lahan sistem pertanian organik lebih tinggi dibandingkan pada lahan sistem pertanian konvensional. Hal ini dikarenakan ketersediaan K-dd tanah juga selaras dengan $\mathrm{pH}$ tanah, karena faktor yang mempengaruhi tersedianya Kalium di dalam tanah, yaitu pH tanah. Menurut Sri dan Suci (2003), K-dd dapat ditingkat oleh sistem pertanian organik, sedangkan untuk kandungan Na-dd pada lahan pertanian konvensional juga lebih rendah dari kedua lahan pada pertanian organik. Hal ini dikarenakan penurunan $\mathrm{Na}-$ dd diikuti dengan penurunan nilai $\mathrm{pH}$ dan kandungan K-dd di dalam tanah.

\section{KESIMPULAN}

Berdasarkan hasil penelitian yang telah dilakukan dapat disimpulkan bahwa terdapat perubahan angka pada indeks kualitas tanah dari lahan sistem pertanian konvensional menjadi lahan sistem pertanian organik dengan kenaikan nilai indeks kualitas tanah berturut-turut sebesar $0,43,0,48$ dan 0,53 sehingga lahan sistem pertanian organik dapat menjadi acuan dalam meningkatkan kualitas tanah berdasarkan indeks kualitas tanah.

\section{DAFTAR PUSTAKA}

Agustina D. (2016). Keanekaragaman dan Kepadatan Cacing Tanah di Arboretum Sumber Brantas dan Lahan Pertanian Sawi Kecamatan Bumiaji Kota Batu. Universitas Islam Negeri Maulana Malik Ibrahim

Altieri M A. (2002). Agroecology: the Science of Natural Resource Management for Poor Farmers in Marginal Environments. Agriculture, Ecosystems and Environment. 93 (13): $1-24$ 
Badgley C, Moghtader J, Quintero E, Zakem E, Chappell M J, Avilés-Vázquez K, Samulon A, Perfecto I. (2007). Organic Agriculture and the Global Food Supply. Renewable Agriculture and Food Systems. 22(2): 86-108

Birkhofer $\mathrm{K}$, Bezemer $\mathrm{T} \mathrm{M}$, Bloem $\mathrm{J}$, Bonkowski M, Christensen S, Dubois D, Ekelund F, Fließbach A, Gunst L, Hedlund K, Mäder P, Mikola J, Robin C, Setälä H, Tatin-Froux F, Van der Putten W H, Scheu S. (2008). LongTerm Organic Farming Fosters Below and Aboveground Biota: Implications for Soil Quality, Biological Control and Productivity. Soil Biology and Biochemistry. 40(9): 2297-2308

Gomiero T, Pimentel D, Paoletti M G. (2011). Environmental Impact of Different Agricultural Management Practices: Conventional vs. Organic Agriculture. Critical Reviews in Plant Sciences, 30(1-2), 95-124

Hardjowigeno S. (2010). Ilmu Tanah. Jakarta: Akademika Pressindo.

Hillel D. (1992). Out of the Earth: Civilization and the Life of the Soil. University of California Press.

Isnaini M. (2006). Pertanian Organik. Yogyakarta: Kreasi Wacana, 247248.
Primadani P. (2008). Pemetaan Kualitas Tanah pada Beberapa Penggunaan Lahan di Kecamatan Jatipuro Kabupaten Karanganyar. Solo: Universitas Sebelas Maret.

Supriyadi S. (2008). Kandungan Bahan Organik sebagai Dasar Pengelolaan Tanah di Lahan Kering Madura. Embryo, 5(2), 176-183.

Sutanto R. (2002). Penerapan Pertanian Organik. Yogyakarta: Kanisius.

Suwantoro A A. (2008). Analisis Pengembangan Pertanian Organik di Kabupaten Magelang (studi kasus di Kecamatan Sawangan). UNDIP Tesis. Universitas Diponegoro. Retrieved from http://eprints.undip.ac.id/16429/1/An dreas_Avelinus_Suwantoro.pdf

Syafruddin (2019). Pertanian Organik: Pertanian Andalan Masa Depan (M. S. Dr. Ismail Sulaiman, S.TP. (ed.)). Bada Aceh: Syiah Kuala University Press.

Vadari T, Dian Nura M S, Handayani S, Sukristiyonubowo. (2014). Perubahan Sifat Fisik Tanah dalam Pertanian Organik. Prosiding Seminar Nasional Pertanian Organik. 12: 143-151. 
Bidang Ilmu Pengetahuan Alam 